\title{
The Effect of Sugammadex on Prothrombin and Activated Partial Thromboplastin Time
}

\author{
Evangelia Samara ${ }^{1}$, Konstantinos Stamatiou ${ }^{2}$, Marina Balanika ${ }^{1}$, Petros Tzimas ${ }^{3}$ \\ 1. Department of Anaesthesiology, Onassis Cardiac Surgery Center, Athens, GRC 2. Department of Urology, Tzaneio \\ General Hospital of Piraeus, Piraeus, GRC 3. Department of Anesthesiology and Postoperative Intensive Care, School \\ of Health Sciences, University of Ioannina, Ioannina, GRC
}

Corresponding author: Evangelia Samara, gelysamara@yahoo.com

\begin{abstract}
Sugammadex is routinely used as an effective neuromuscular blockade reversal agent. Several studies have indicated that it may prolong the prothrombin time (PT) and the activated partial thromboplastin time (aPTT). This review gathers the relevant in vivo studies to accumulate knowledge on the subject. Nine studies were included. According to the results, sugammadex seems to lead to a transient increase in aPTT and PT values, compared to standard care. However, the clinical impact seems to be trivial. Nevertheless, the trials' findings reveal great heterogeneity, preventing a meta-analysis. Therefore, more well-designed studies are needed to lead to prudent conclusions.

Categories: Anesthesiology

Keywords: sugammadex, coagulation, bleeding, hemostasis, prothrombin time (pt), activated partial thromboplastin time (aptt)
\end{abstract}

Review began 04/02/2021 Review ended 04/07/2021 Published 04/16/2021

๑) Copyright 2021 Samara et al. This is an open access article distributed under the terms of the Creative Commons Attribution License CC-BY 4.0., which permits unrestricted use, distribution, and reproduction in any medium, provided the original author and source are credited.

\section{Introduction And Background}

Sugammadex (Bridion ${ }^{\circledR}$; Merck \& Company, Inc., Whitehouse Station, NJ) is a modified $\gamma$-cyclodextrin that is routinely used in Europe as an effective reversal agent for rocuronium- and vecuroniuminduced neuromuscular blockade since 2008. In December 2015, sugammadex was also approved by the Food and Drug Administration (FDA) for use in the United States after it was initially rejected over concerns regarding anaphylaxis, as well as the effects of sugammadex on coagulation [1].

Sugammadex binds and shifts the concentration gradient of rocuronium away from the neuromuscular junction [2]. Its efficacy and safety have been well-established, and it is associated with a lower risk of adverse events compared with neostigmine [3-4].

Although the most common adverse reactions reported are vomiting, dry mouth, tachycardia, hypotension [5], as well as anaphylactic reactions [6-7], several studies have indicated it may interfere with hemostasis by prolonging the prothrombin time (PT) and the activated partial thromboplastin time (aPTT) [8-9].

It is also recommended that "coagulation parameters should be carefully monitored in patients with known coagulopathies, being treated with therapeutic anticoagulation, receiving thromboprophylaxis drugs other than heparin and low molecular weight heparin, or receiving thromboprophylaxis drugs and who then receive a dose of $16 \mathrm{mg} / \mathrm{kg}$ sugammadex" [10].

In this review, we aimed to delineate the knowledge of the effect of sugammadex on PT and aPTT in vivo.

\section{Review}

A search of PubMed, the online bibliographic database of the US National Library of Medicine was performed, using the following terms: sugammadex; coagulation; bleeding; hemostasis; prothrombin time; activated partial thromboplastin time.

Inclusion criteria for this review were: (i) clinical studies evaluating sugammadex's effect on hemostasis, (ii) in the English language, and (iii) conducted in vivo.

Exclusion criteria were: (i) case reports and reviews, (ii) non-English language, (iii) studies in vitro, and (iv) studies evaluating hemostasis, not measuring PT and/ or aPTT.

Two investigators performed the search and selection to ensure that only relevant articles were included. Duplicate articles and articles not meeting the inclusion criteria were excluded from further analysis.

The two investigators excluded without disagreement 65 out of the 79 articles found in PubMed as 
duplicates or irrelevant and proceeded to the full-text reading of the remaining 14 articles. One study was excluded for not being written in the English language [11], three for having been conducted in an in vitro environment [12-14], and one for using data from previous studies to predict the outcome [15]. Nine studies were finally selected to assess the effect of sugammadex in aPTT and PT. The Preferred Reporting Items for Systematic Reviews and Meta-Analyses (PRISMA) flow diagram describing the steps of study selection can be found in Figure 1 [16].

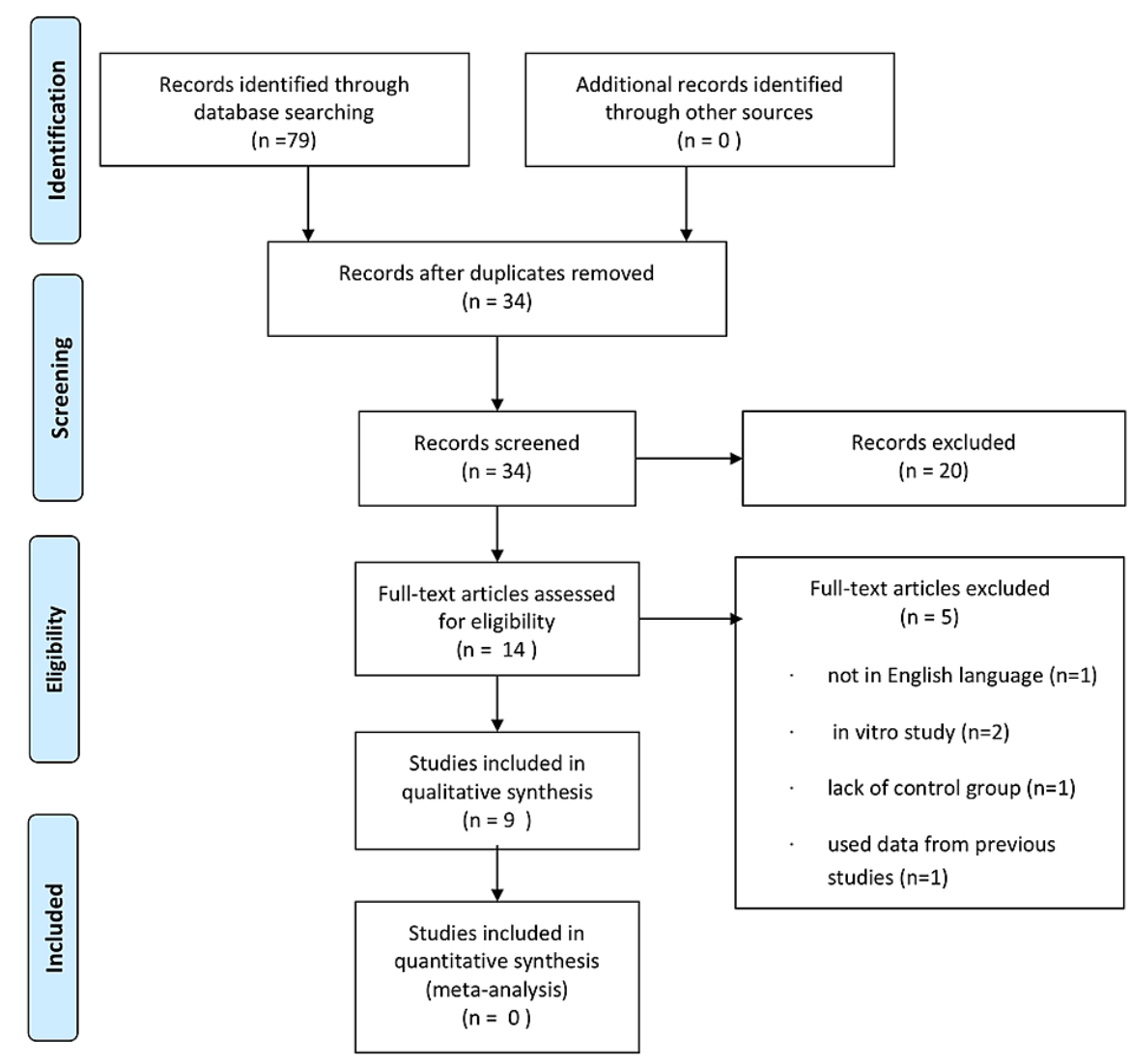

FIGURE 1: Preferred Reporting Items for Systematic Reviews and MetaAnalyses (PRISMA)-based flow diagram displaying the study selection

In 2014, de Kam et al. measured PT and aPTT value changes in eight healthy volunteers after sugammadex 4 $\mathrm{mg} / \mathrm{kg}$ or $16 \mathrm{mg} / \mathrm{kg}$ and placebo administration in a randomized crossover three-period study [8]. The endpoint was the area under the curve (AUC) 2 to $60 \mathrm{~min}$ after the dosing. According to the results, administration of sugammadex $4 \mathrm{mg} / \mathrm{kg}$ and $16 \mathrm{mg} / \mathrm{kg}$ led to a geometric mean ratio (sugammadex versus placebo) for AUC 2 to 60 min was 1.085 (95\% CI 0.888 - 1.325) and 1.019 (0.868 - 1.195), respectively, for aPTT and 1.047 (0.904 - 1.213) and 1.096 (0.953 - 1.261), respectively, for PT (international normalized ratio (INR)). The mean value of aPTT and PT(INR) augmented up to $22 \%$ after sugammadex $16 \mathrm{mg} / \mathrm{kg}$ administration compared to placebo administration. All the above-mentioned differences occurred within 30 minutes after administration.

One year earlier, de Kam et al. evaluated the possibility of interaction between sugammadex and aspirin in platelet aggregation [9]. The researchers conducted a randomized, double-blind, placebo-controlled crossover study in 26 healthy male volunteers. The subjects received either intravenous placebo, sugammadex $4 \mathrm{mg} / \mathrm{kg}$, or placebo/sugammadex with aspirin $75 \mathrm{mg}$, taken orally once a day. The primary endpoint was the interaction of sugammadex with aspirin in platelet aggregation. The effect in aPTT and bleeding time was also evaluated. Platelet aggregation and aPTT value were evaluated by geometric mean ratio for the AUC 3 to 30 minutes after dosing. Bleeding time was measured five minutes after administration. Data analysis showed that the ratio of platelet aggregation for aspirin combined with sugammadex to aspirin alone was 1.01. The ratio of bleeding time for sugammadex/aspirin to aspirin/placebo was 1.20 . The results showed no clinically significant reduction in platelet aggregation in sugammadex $4 \mathrm{mg} / \mathrm{kg}$ administration combined with aspirin [9]. 
A study by Raft et al. aimed to analyze the effect of sugammadex in usual clotting and bleeding tests in a clinical environment [17]. It was a prospective observational study in which 142 patients were included. The patients, scheduled for elective laparotomy, were divided into three groups to receive sugammadex $2 \mathrm{mg} / \mathrm{kg}$, $4 \mathrm{mg} / \mathrm{kg}$, and placebo. aPTT, PT, hemoglobin $(\mathrm{Hb})$, and hematocrit (Hct) were measured right before and after sugammadex administration. Analysis showed no correlation of sugammadex to prolonged bleeding time or lower Hb level [17].

Moon et al. compared postoperative coagulation profiles in living donors undergoing hepatectomy [18]. The two patient groups received either sugammadex $4 \mathrm{mg} / \mathrm{kg}$ or pyridostigmine $0.25 \mathrm{mg} / \mathrm{kg}$ to reverse rocuronium-induced neuromuscular blockade. Endpoints were laboratory testing of PT, aPTT, Hb, and platelet count, as well as a clinical evaluation of postoperative bleeding. Out of 992 donors, 383 received pyridostigmine, and 609 received sugammadex as a reversal agent. There were no significant differences between the two groups in $\mathrm{Hb}$, platelet count level drop, PT, or aPTT values. Two incidents of hemorrhage 24 hours postoperatively $(0.3 \%)$ were reported in the pyridostigmine group, while no such incidents occurred in the sugammadex group. Anesthetic time, as well as in-hospital postoperative stay, were significantly longer in the pyridostigmine group compared to the sugammadex group.

Tas et al. investigated the effect of sugammadex in coagulation values and postoperative bleeding after septoplasty [19]. In this randomized, controlled study, 50 patients were divided into two groups to receive either neostigmine or sugammadex. Blood samples were acquired 120 minutes postoperatively, and PT, aPTT, and INR values were compared to the respective preoperative values. Postoperative bleeding was evaluated by the blood amount absorbed by the nose tampon during the first three hours after surgery. Postoperative bleeding was significantly higher in the sugammadex group. No difference in the PT, aPTT, or INR values was found between the two groups. Sugammadex was correlated with more postoperative bleeding compared to neostigmine.

de Kam et al. also conducted a two-part, randomized, double-blind, placebo-controlled, four-period crossover study in healthy males in 2014 [20]. Each subject received $40 \mathrm{mg}$ of enoxaparin, 5,000 units of unfractionated heparin (UFH), or placebo followed by 4 or $16 \mathrm{mg} / \mathrm{kg}$ sugammadex or placebo. Anti-Xa activity and aPTT were evaluated for 30 minutes after the sugammadex/placebo administration. Geometric mean ratios (GMRs) and their two-sided $90 \%$ confidence limits were obtained to compare the sugammadex group versus the placebo group. They concluded that neither of the sugammadex dosages resulted in a clinically important effect, as this was specified a priori [20].

In the largest trial included in this review, Rahe-Mayer et al. investigated the effect of sugammadex in postoperative bleeding and clotting time [21]. It was a randomized, double-blind study, including patients undergoing total knee or hip replacement, as well as hip fracture surgery, while already on thromboprophylaxis medication. Patients received either sugammadex $4 \mathrm{mg} / \mathrm{kg}$ or standard care (neostigmine or nothing) to reverse the neuromuscular blockade induced by rocuronium or vecuronium. Out of 1,198 randomized patients, 1,184 finally received either sugammadex $(n=596)$ or standard care $(n=588)$. Hemorrhage incidents reported 24 hours postoperatively were 17 (2.9\%) in the sugammadex group and 24 (4.1\%) in the standard care group. A 5.5\% increase in aPTT value, as well as $3.0 \%$ in the PT value, was recorded in the sugammadex group compared to the standard care group 10 minutes after the reversal agent administration. There was no difference between sugammadex and the standard care group in terms of blood loss measurement. Researchers concluded that sugammadex induced a limited, temporary increase in PT and aPTT values, but this was not correlated to augmented hemorrhage risk compared to standard care.

Targeting a specific surgical population, Carron et al. studied the effect of sugammadex in coagulation among morbidly obese patients undergoing bariatric surgery [22]. The two different groups received either sugammadex $2 \mathrm{mg} / \mathrm{kg}$ or $4 \mathrm{mg} / \mathrm{kg}$, whereas no placebo group was assigned. There was a statistically important difference in the aPTT value before and after the sugammadex administration but not between the two different groups. As for the PT value, no statistically important difference was observed in any of the groups.

In the most recent study done in 2020, Kang et al. allocated 100 patients undergoing elective arthroscopic shoulder surgery in two groups to receive either sugammadex $2 \mathrm{mg} / \mathrm{kg}$ or sugammadex $4 \mathrm{mg} / \mathrm{kg}$ [23]. Blood samples were obtained before and $15 \mathrm{~min}$ after sugammadex administration. Laboratory testing included PT, aPTT, platelet count, and thromboelastography (TEG)-derived measurements. According to the results, the PT value was significantly greater after the sugammadex administration in both groups with no difference when the two groups were compared. Nevertheless, even the prolonged PT values did not exceed the normal range. There was no difference reported for aPTT values.

The characteristics of the nine studies concerning the type, the conducting time, the compared groups, and the endpoints are summarized in Table 1. 


\section{Cureus}

\begin{tabular}{|c|c|c|c|c|c|}
\hline Study & Study type & $\begin{array}{l}\text { Number of } \\
\text { participants }\end{array}$ & Groups & Endpoints & $\begin{array}{l}\text { Results } \\
\text { concerning } \\
\text { PT/aPTT }\end{array}$ \\
\hline $\begin{array}{l}\text { de } \\
\text { Kam } \\
\text { et al. } \\
(2014) \\
{[8]}\end{array}$ & $\begin{array}{l}\text { Randomized } \\
\text { three period } \\
\text { crossover } \\
\text { study }\end{array}$ & 8 & $\begin{array}{l}\text { 1) Placebo; 2) sugammadex } 4 \mathrm{mg} / \mathrm{kg} \text {; 3) sugammadex } 16 \\
\mathrm{mg} / \mathrm{kg}\end{array}$ & $\begin{array}{l}\mathrm{AUC}_{2-60 \mathrm{~min}} \\
\mathrm{aPPT}-{ }^{*} \mathrm{MAX} \mathrm{X}_{0-} \\
12 \mathrm{hr}, \mathrm{PT}- \\
{ }^{*} \mathrm{MAX}_{0-12 \mathrm{hr}} \\
\text { geometric } \\
\text { mean ratio }\end{array}$ & $\begin{array}{l}\text { PT and aPTT } \\
\text { dose- } \\
\text { dependent } \\
\text { increase in } \\
\text { the } \\
\text { sugammadex } \\
\text { groups }\end{array}$ \\
\hline $\begin{array}{l}\text { de } \\
\text { Kam } \\
\text { et al. } \\
\text { (2013) } \\
\text { [9] }\end{array}$ & $\begin{array}{l}\text { Randomized } \\
\text { crossover } \\
\text { study }\end{array}$ & 26 & $\begin{array}{l}\text { 1) Sugammadex } 4 \mathrm{mg} / \mathrm{kg} \text { + aspirin; 2) sugammadex } 4 \\
\mathrm{mg} / \mathrm{kg} \text {; 3) placebo; 4) placebo + aspirin; 5) aspirin }\end{array}$ & $\begin{array}{l}\text { Platelet } \\
\text { aggregation, } \\
\text { aPPT, PT }\end{array}$ & $\begin{array}{l}\text { PT and aPTT } \\
\text { increase in } \\
\text { sugammadex } \\
\text { groups }\end{array}$ \\
\hline $\begin{array}{l}\text { Raft et } \\
\text { al. } \\
(2015) \\
{[17]}\end{array}$ & $\begin{array}{l}\text { Prospective } \\
\text { observational } \\
\text { study }\end{array}$ & 142 & $\begin{array}{l}\text { 1) Placebo; 2) sugammadex } 2 \mathrm{mg} / \mathrm{kg} \text {; 3) sugammadex } 4 \\
\mathrm{mg} / \mathrm{kg}\end{array}$ & $\begin{array}{l}\text { aPPT, PT, } \\
\text { hemoglobin } \\
(\mathrm{Hb}) \text {, } \\
\text { hematocrit } \\
(\mathrm{Ht})\end{array}$ & $\begin{array}{l}\text { No increase in } \\
\text { PT and/or } \\
\text { aPTT in any of } \\
\text { the groups }\end{array}$ \\
\hline $\begin{array}{l}\text { Moon } \\
\text { et al. } \\
(2018) \\
{[18]}\end{array}$ & $\begin{array}{l}\text { Retrospective } \\
\text { observational } \\
\text { study }\end{array}$ & 992 & 1) Sugammadex $4 \mathrm{mg} / \mathrm{kg}$; 2) pyridostigmine $0.25 \mathrm{mg} / \mathrm{kg}$ & $\begin{array}{l}\text { PT (INR), } \\
\text { aPPT, } \\
\text { hemoglobin, } \\
\text { platelet count }\end{array}$ & $\begin{array}{l}\mathrm{PT} \uparrow \mathrm{PT} \uparrow ; \text { no } \\
\text { difference } \\
\text { between the } \\
\text { two groups }\end{array}$ \\
\hline $\begin{array}{l}\text { las et } \\
\text { al. } \\
(2015) \\
{[19]}\end{array}$ & $\begin{array}{l}\text { Randomized } \\
\text { control study }\end{array}$ & 50 & $\begin{array}{l}\text { 1) Sugammadex } 2 \mathrm{mg} / \mathrm{kg} \text {; 2) neostigmine } 0.05 \mathrm{mg} / \mathrm{kg}+ \\
\text { atropine } 0.02 \mathrm{mg} / \mathrm{kg}\end{array}$ & $\begin{array}{l}\text { PT, aPPT, } \\
\text { bleeding } \\
\text { events }\end{array}$ & $\begin{array}{l}\text { No difference } \\
\text { in PT/ aPTT } \\
\text { values. More } \\
\text { bleeding in } \\
\text { sugammadex } \\
\text { group. }\end{array}$ \\
\hline $\begin{array}{l}\text { de } \\
\text { Kam } \\
\text { et al. } \\
(2014) \\
{[20]}\end{array}$ & $\begin{array}{l}\text { Randomized } \\
\text { crossover } \\
\text { study }\end{array}$ & $\begin{array}{l}\text { Part 1: } 12 \\
\text { Part 2: } 40\end{array}$ & $\begin{array}{l}\text { Period 1: enoxaparin } 40 \mathrm{mg} \text { and sugammadex } 4 \mathrm{mg} / \mathrm{kg} \text { or } \\
\text { sugammadex } 16 \mathrm{mg} / \mathrm{kg} \text { or placebo; Period 2: UFH } 5000 \text { IU } \\
\text { and sugammadex } 4 \mathrm{mg} / \mathrm{kg} \text { or sugammadex } 16 \mathrm{mg} / \mathrm{kg} \text {, or } \\
\text { placebo. Period 3: Placebo and sugammadex } 4 \mathrm{mg} / \mathrm{kg} \text { or } \\
\text { sugammadex } 16 \mathrm{mg} / \mathrm{kg} \text {, or placebo; Period } 4: \text { Placebo }\end{array}$ & $\begin{array}{l}\text { Anti-Xa } \\
\text { activity and } \\
\text { aPTT } \\
\text { Geometric } \\
\text { mean ratios }\end{array}$ & $\begin{array}{l}\text { Dose- } \\
\text { dependent } \\
\text { aPTT and PT } \\
\text { increase in } \\
\text { sugammadex } \\
\text { groups. }\end{array}$ \\
\hline $\begin{array}{l}\text { Rahe- } \\
\text { Meyer } \\
\text { et al. } \\
\text { (2014) } \\
\text { [21] }\end{array}$ & $\begin{array}{l}\text { Randomized } \\
\text { control study }\end{array}$ & 1,184 & 1) Placebo or neostigmine; 2) sugammadex $4 \mathrm{mg} / \mathrm{kg}$ & $\begin{array}{l}\text { PT (INR), } \\
\text { aPPT }\end{array}$ & $\begin{array}{l}\text { PT and aPTT } \\
\text { value increase } \\
\text { in } \\
\text { sugammadex } \\
\text { group }\end{array}$ \\
\hline $\begin{array}{l}\text { Carron } \\
\text { et al. } \\
(2018) \\
{[22]}\end{array}$ & $\begin{array}{l}\text { Prospective } \\
\text { observational } \\
\text { study }\end{array}$ & 60 & 1) Sugammadex 2 mg/kg; 2) sugammadex 4 mg/kg & $\begin{array}{l}\text { Blood } \\
\text { coagulation, } \\
\text { postoperative } \\
\text { bleeding }\end{array}$ & $\begin{array}{l}\text { PT }-/ \text { aPTT } \uparrow \\
\text { in both } \\
\text { groups }\end{array}$ \\
\hline $\begin{array}{l}\text { Kang } \\
\text { et al. } \\
(2020) \\
{[23]}\end{array}$ & $\begin{array}{l}\text { Randomized } \\
\text { study }\end{array}$ & 100 & 1) Sugammadex 2 mg/kg; 2) sugammadex 4 mg/kg & & $\begin{array}{l}\mathrm{PT} \uparrow / \mathrm{aPTT}- \\
\text { in both } \\
\text { groups }\end{array}$ \\
\hline
\end{tabular}

\section{TABLE 1: Characteristics of the Nine Studies Included in the Review}

*maximum value within 12 hours after administration

aPTT: activated partial thromboplastin time; AUC: area under the curve; INR: international normalized ratio; PT: prothrombin time; UFH: unfractionated heparin 
According to Table 1, three out of nine studies were randomized crossover trials [8-9, 20], two were randomized controlled trials [19, 21], one was a randomized trial without a control group [23], two were prospective observational studies [17, 22], and one was a retrospective observational study [18]. In three out of nine trials, sugammadex was used in the dosage of $4 \mathrm{mg} / \mathrm{kg}[9,18,21]$, in three out of nine trials the sugammadex dosage was $2 \mathrm{mg} / \mathrm{kg}$ and $4 \mathrm{mg} / \mathrm{kg}$ [17, 22-23], in two out of nine trials, sugammadex 4 $\mathrm{mg} / \mathrm{kg}$ and $16 \mathrm{mg} / \mathrm{kg}$ were used [8, 20], and finally, in one out of nine, the dosage for sugammadex was 2 $\mathrm{mg} / \mathrm{kg}[19]$.

Moreover, in two out of nine trials, the control group received a placebo [8], [17]. In one out of nine, the control groups received placebo, aspirin and placebo with aspirin [9]. In one trial, the control groups received a placebo, a placebo with enoxaparin, or a placebo with heparin [20]. In one out of nine, the control group received pyridostigmine [18]. In two out of nine trials, the control group received neostigmine [19] or either neostigmine or a placebo [21], whereas two trials did not include a control group [22-23].

PT and/or aPTT were found to increase after sugammadex administration in seven out of the nine studies [89, 18, 20-23]. However, the increase seemed to be transient and dose-dependent. Indeed, the greatest increase occurred in the sugammadex $16 \mathrm{mg} / \mathrm{kg}$ dosing, which, in a clinical setting, is used for immediate neuromuscular blockade reversal. In such cases, the surgery is most probably postponed so a bleeding predisposition is no longer a concern.

The authors intended to conduct a meta-analysis using the data of the studies included in this review. However, this was not possible as the effect size measures in these studies were not comparable and the domain for which the effect would be meta-analyzed was not clearly delimited.

\section{Conclusions}

According to the literature, sugammadex temporarily increases aPTT and PT values, as compared to traditional reversal agents. Nevertheless, there is heterogeneity between the trials' findings. Therefore, a meta-analysis of the provided data could not be conducted. Although the transient changes of the examined parameters do not seem to have a clinical impact, sugammadex's interference with coagulation has been said to be just an in vitro artifact. More well-designed studies are needed to make prudent conclusions.

\section{Additional Information}

\section{Disclosures}

Conflicts of interest: In compliance with the ICMJE uniform disclosure form, all authors declare the following: Payment/services info: All authors have declared that no financial support was received from any organization for the submitted work. Financial relationships: All authors have declared that they have no financial relationships at present or within the previous three years with any organizations that might have an interest in the submitted work. Other relationships: All authors have declared that there are no other relationships or activities that could appear to have influenced the submitted work.

\section{References}

1. Summary Review for Regulatory Action, Application 022225Orig1s000 . (2015). Accessed: April 9, 2021: http://www.accessdata.fda.gov/drugsatfda_docs/nda/2015/0222250rig1s000SumR.pdf.

2. Naguib M: Sugammadex: another milestone in clinical neuromuscular pharmacology . Anesth Analg. 2007, 104:575-81. 10.1213/01.ane.0000244594.63318.fC

3. Carron M, Zarantonello F, Tellaroli P, Ori C: Efficacy and safety of sugammadex compared to neostigmine for reversal of neuromuscular blockade: a meta-analysis of randomized controlled trials. J Clin Anesth. 2016, 35:1-12. 10.1016/j.jclinane.2016.06.018

4. Hristovska AM, Duch P, Allingstrup M, Afshari A: Efficacy and safety of sugammadex versus neostigmine in reversing neuromuscular blockade in adults. Cochrane Database Syst Rev. 2017, 8:CD012763. 10.1002/14651858.CD012763

5. Welliver M, McDonough J, Kalynych N, Redfern R: Discovery, development, and clinical application of sugammadex sodium, a selective relaxant binding agent. Drug Des Devel Ther. 2009, 2:49-59. 10.2147/dddt.s2757

6. Tsur A, Kalansky A: Hypersensitivity associated with sugammadex administration: a systematic review . Anaesthesia. 2014, 69:1251-57. 10.1111/anae.12736

7. Escher AR Jr, Cohen JB: Anaphylaxis induced by sugammadex in a patient with papillary serous carcinoma of the uterine adnexa undergoing exploratory laparotomy. Cureus. 2019, 11:e3871. 10.7759/cureus.3871

8. de Kam PJ, Grobara P, Prohn M, et al.: Effects of sugammadex on activated partial thromboplastin time and prothrombin time in healthy subjects. Int J Clin Pharmacol Ther. 2014, 52:227-36. 10.5414/CP201976

9. de Kam PJ, El Galta R, Kruithof AC, et al.: No clinically relevant interaction between sugammadex and aspirin on platelet aggregation and coagulation parameters. Int J Clin Pharmacol Ther. 2013, 51:976-85. 10.5414/CP201970

10. Bridion ${ }^{\circledR}$ (sugammadex) Injection, for intravenous use. Initial U.S. Approval: 2015 . (2015). Accessed: April 9, 2021: http://www.accessdata.fda.gov/drugsatfda_docs/label/2015/022225lbl.pdf.

11. Raft J, Betala Belinga JF, Jurkolow G, Desandes E, Longrois D, Meistelman C: Clinical evaluation of postsurgical bleeding after a sugammadex injection (Article in French). Ann Fr Anesth Reanim. 2011, 30:714-17. 


\section{Cureus}

10.1016/j.annfar.2011.04.019

12. Lee IO, Kim YS, Chang HW, Kim H, Lim BG, Lee M: In vitro investigation of the effects of exogenous sugammadex on coagulation in orthopedic surgical patients. BMC Anesthesiol. 2018, 18:56.

10.1186/s12871-018-0519-3

13. Dirkmann D, Britten MW, Pauling H, Weidle J, Volbracht L, Görlinger K, Peters J: Anticoagulant effect of sugammadex: just an in vitro artifact. Anesthesiology. 2016, 124:1277-85. 10.1097/ALN.0000000000001076

14. Kruithof AC, Kluft C, de Kam PJ, Laterveer GH, Moerland M, Burggraaf J: Interactions of sugammadex with various anticoagulants. Int J Clin Pharmacol Ther. 2020, 58:395-403. 10.5414/CP203733

15. Moher D, Liberati A, Tetzlaff J, Altman DG; PRISMA Group: Preferred reporting items for systematic reviews and meta-analyses: the PRISMA statement. PLoS Med. 2009, 6:e1000097.

10.1371/journal.pmed.1000097

16. Bosch R, van Lierop MJ, de Kam PJ, et al.: A PK-PD model-based assessment of sugammadex effects on coagulation parameters. Eur J Pharm Sci. 2016, 84:9-17. 10.1016/j.ejps.2015.12.028

17. Raft J, Guerci P, Harter V, Fuchs-Buder T, Meistelman C: Biological evaluation of the effect of sugammadex on hemostasis and bleeding. Korean J Anesthesiol. 2015, 68:17-21. 10.4097/kjae.2015.68.1.17

18. Moon YJ, Kim SH, Kim JW, Lee YK, Jun IG, Hwang GS: Comparison of postoperative coagulation profiles and outcome for sugammadex versus pyridostigmine in 992 living donors after living-donor hepatectomy. Medicine (Baltimore). 2018, 97:e0129. 10.1097/MD.0000000000010129

19. Taş N, Korkmaz H, Yağan Ö, Korkmaz M: Effect of sugammadex on postoperative bleeding and coagulation parameters after septoplasty: a randomized prospective study. Med Sci Monit. 2015, 21:2382-86. 10.12659/MSM.894971

20. de Kam PJ, Kruithof AC, van Lierop MJ, et al.: Lack of a clinically relevant effect of sugammadex on anti-Xa activity or activated partial thromboplastin time following pretreatment with either unfractionated or lowmolecular-weight heparin in healthy subjects. Int J Clin Pharmacol Ther. 2014, 52:631-41. 10.5414/CP202091

21. Rahe-Meyer N, Fennema H, Schulman S, et al.: Effect of reversal of neuromuscular blockade with sugammadex versus usual care on bleeding risk in a randomized study of surgical patients. Anesthesiology. 2014, 121:969-77. 10.1097/ALN.0000000000000424

22. Carron M, Bertini D, Prandini T, et al.: Effect of sugammadex on coagulation as detected by rotational thromboelastometry in morbidly obese patients. Minerva Anestesiol. 2018, 84:178-88. 10.23736/S03759393.17.11856-0

23. Kang WS, Lim H, Kim BS, Lee Y, Hahm KD, Kim SH: Assessment of the effects of sugammadex on coagulation profiles using thromboelastographic parameters. Sci Rep. 2020, 10:11179. 10.1038/s41598-02068164-2 